\title{
Silica dissolution as a route to octaanionic silsesquioxanes
}

\section{K. H. Kang ${ }^{\dagger}$ and R. M. Laine*,}

Department of Materials Science and Engineering, and the Macromolecular Science and Engineering Program, University of Michigan, Ann Arbor, MI 48109-2136, USA

Received 9 January 2006; Revised 11 March 2006; Accepted 11 March 2006

\begin{abstract}
The octaanion, $\left[\mathrm{OSiO}_{1.5}\right]_{8}{ }^{8-}(\mathrm{OA})$ is a low cost, discrete nano silica particle that can be made directly from high surface area, amorphous silica reacted with $\mathrm{Me}_{4} \mathrm{NOH}$ in water alcohol mixtures. It would be ideal if $\mathrm{Me}_{4} \mathrm{NOH}$ could be formed in situ from, for example, $\mathrm{Me}_{4} \mathrm{NCl}$ and $\mathrm{NaOH}$, as long known in the literature. This process would reduce costs and enable recycling of $\mathrm{Me}_{4} \mathrm{NCl}$ produced in the functionalization of $\mathrm{OA}$ with chlorosilanes, $\mathrm{RMe}_{2} \mathrm{SiCl}$, to form $\left[\mathrm{RMe}_{2} \mathrm{SiOSiO}_{1.5}\right]_{8}$ organic/inorganic hybrid nanobuilding blocks. Kinetic studies were conducted to assess base-promoted dissolution of fumed silica $\left(25 \mathrm{~m}^{2} / \mathrm{g}\right)$ as a function of concentrations, times, etc., to form the octaanion $\left[\mathrm{OSiO}_{1.5}\right]_{8}{ }^{8-}$ using $\mathrm{Me}_{4} \mathrm{NOH}, \mathrm{NaOH}$ and mixtures of $\mathrm{NaOH} / \mathrm{Me}_{4} \mathrm{NCl}$. Surprisingly, we find that small amounts of $\mathrm{Me}_{4} \mathrm{NCl}$ greatly inhibit the dissolution reaction for reasons that are as yet unknown. Copyright $\odot$ 2006 John Wiley \& Sons, Ltd.
\end{abstract}

KEYWORDS: octaanionic silsesquioxanes; nano building blocks; silica dissolution; tetramethylammonium hydroxide

\section{INTRODUCTION}

We recently described kinetic studies on $\mathrm{RMe}_{3} \mathrm{NOH}(\mathrm{R}=\mathrm{Me}$ or $\mathrm{CH}_{2} \mathrm{CH}_{2} \mathrm{OH}$ ) promoted dissolution of rice hull ash (RHA) as a simple, direct and high yield route to the octaanions, $\left[\mathrm{OSiO}_{1.5}\right]_{8}\left[\mathrm{NMe}_{3} \mathrm{R}\right]_{8} \cdot{ }^{1,2}$ As a result of these studies, we suggested that the choline derivative $\left(\mathrm{R}=\mathrm{CH}_{2} \mathrm{CH}_{2} \mathrm{OH}\right)$ resembles a potential intermediate in the mechanism whereby diatoms extract silica from seawater, and store and transport it prior to using it to form the intricate structures within which they live. The implication is that the biosilicification process wherein millions of tons of silica, present in seawater as $\mathrm{Si}(\mathrm{OH})_{4}$, is transformed into biological structures may use nanosized silica building blocks like $\left[\mathrm{OSiO}_{1.5}\right]_{8}{ }^{8-}$ in the process. Also of considerable importance is the fact that $\left[\mathrm{OSiO}_{1.5}\right]_{8}{ }^{8-}(\mathrm{OA})$ is a low-cost precursor to organic/inorganic nanobuilding blocks of the type $\left[\mathrm{RMe}_{2} \mathrm{SiOSiO}_{1.5}\right]_{8}$ where $\mathrm{R}=$ alkyl, alkenyl, epoxy, etc., which are of considerable potential for numerous academic and commercial applications. ${ }^{1-11}$

* Correspondence to: R. M. Laine, University of Michigan, Ann Arbour, MI 48109-2136.

E-mail: talsdad@umich.edu

${ }^{\dagger}$ On leave from Korean Chemicals Company.

ҒThis paper is dedicated to Professor Ulrich Schubert on the occasion of his 60 th birthday.

Contract/grant sponsor: USDA; Contract/grant number: 2005-00442.
As an extension of the initial work, we sought to produce $\mathrm{Me}_{4} \mathrm{NOH}$ in situ by reaction of $\mathrm{NaOH}$ with $\mathrm{Me}_{4} \mathrm{NCl}$, coincidentally forming relatively insoluble and innocuous $\mathrm{NaCl}$ using the hydroxide synthesis process. ${ }^{12-14} \mathrm{NaCl}$ was not expected to affect the process, although sodium ions are known to greatly change the composition of soluble silicate ions in solution. ${ }^{15-17}$ The impetus for this effort was to demonstrate the potential to recycle $\mathrm{Me}_{4} \mathrm{NCl}$, a byproduct of the formation of $\left[\mathrm{RMe}_{2} \mathrm{SiOSiO}_{1.5}\right]_{8}$ from OA and $\mathrm{RMe}_{2} \mathrm{SiCl}$. This approach would make the synthesis of the nanobuilding blocks $\left[\mathrm{RMe}_{2} \mathrm{SiOSiO}_{1.5}\right]_{8}$ highly costeffective. We report here the surprising observation that the chloride ion greatly affects the extraction of silica from RHA to produce OA.

\section{EXPERIMENTAL}

\section{Materials}

All chemicals were reagent-grade, purchased from standard vendors and used as received except ethylene glycol $\left(\mathrm{EGH}_{2}\right)$. $\mathrm{EGH}_{2}$ used in these experiments was: (1) purchased from standard vendors and used as received, or (2) recycled from reaction distillate by distillation under $\mathrm{N}_{2}$. The silica used here is fumed silica received as a gift from Cabot Inc. It is amorphous and its specific surface area is $25 \mathrm{~m}^{2} / \mathrm{g}$. All 
reactions were carried out under $\mathrm{N}_{2}$ to minimize the chances of exposing the solution to air or moisture.

\section{General methods}

Standard conditions for kinetic studies

In a $100 \mathrm{~mL}$ round-bottom flask containing $50 \mathrm{ml} \mathrm{EGH}_{2}$ and selected quantities of tetramethylammonium hydroxide hydrate $\left[\mathrm{Me}_{4} \mathrm{NOH}-5 \mathrm{H}_{2} \mathrm{O}\right]$, sodium hydroxide $(\mathrm{NaOH})$ or tetramethylammonium chloride $\left[\mathrm{Me}_{4} \mathrm{NCl}\right.$ ] were added. In order to dissolve $\mathrm{Me}_{4} \mathrm{NOH}-5 \mathrm{H}_{2} \mathrm{O}, \mathrm{NaOH}$ or $\mathrm{Me}_{4} \mathrm{NCl}$, the solution was stirred for $3 \mathrm{~h}$. Then $1.8 \mathrm{~g}$ of silica $(30 \mathrm{mmol})$ was added to the flask and the mixture stirred for $10 \mathrm{~min}$. The flask, equipped with magnetic stirring and standard distillation apparatus, was immersed in an oil bath preheated to $125 \pm 2{ }^{\circ} \mathrm{C}$ for a pre-set reaction time. The flask was then cooled quickly in ice water. The undissolved silica was separated from vacuum filtration. This undissolved silica was washed with $20 \mathrm{ml}$ dry ethanol. The recovered silica was then dried at $130^{\circ} \mathrm{C}$ for $1 \mathrm{~h}$, weighed and the amount of silica dissolved determined. All experiments were repeated at least twice.

\section{Effects of $\left[\mathrm{Me}_{4} \mathrm{NOH} \cdot 5 \mathrm{H}_{2} \mathrm{O}\right]$ on silica dissolution}

$\mathrm{SiO}_{2}(1.8 \mathrm{~g}, 30.0 \mathrm{mmol})$ and $33-100 \mathrm{~mol} \% \mathrm{Me}_{4} \mathrm{NOH} 5 \mathrm{H}_{2} \mathrm{O}$ $(1.8-5.5 \mathrm{~g}, 10-30 \mathrm{mmol})$ were added to $50 \mathrm{ml} \mathrm{EGH}$ and standard reaction conditions were applied. The reaction time was set to $1 \mathrm{~h}$. The results are shown in Fig. 2 .

\section{Effects of reaction time on silica dissolution}

$\mathrm{SiO}_{2}(1.8 \mathrm{~g}, 30.0 \mathrm{mmol})$ and $100.0 \mathrm{~mol} \% \mathrm{Me}_{4} \mathrm{NOH} 5 \mathrm{H}_{2} \mathrm{O}(5.5 \mathrm{~g}$, $30 \mathrm{mmol}$ ) were added to $50 \mathrm{ml} \mathrm{EGH}_{2}$ and standard reaction conditions were applied. Reaction times were set to 1, 2, 3 or $4 \mathrm{~h}$. The results are shown in Fig. 3.

\section{Effects of $\left[\mathrm{Me}{ }_{4} \mathrm{NOH} \cdot 5 \mathrm{H}_{2} \mathrm{O}\right]$ and $\left[\mathrm{Me}{ }_{4} \mathrm{NCl}\right]$ on silica dissolution}

$\mathrm{SiO}_{2}(1.8 \mathrm{~g}, 30 \mathrm{mmol}), \mathrm{Me}_{4} \mathrm{NOH} 5 \mathrm{H}_{2} \mathrm{O}(5.5 \mathrm{~g}, 30 \mathrm{mmol})$ and $0-33.3 \mathrm{~mol} \% \mathrm{Me}_{4} \mathrm{NCl}(0-3.3 \mathrm{~g}, 0-30 \mathrm{mmol})$ were added to $50 \mathrm{ml} \mathrm{EGH} 2$ and reacted under standard reaction conditions. The reaction time was set to $1.0 \mathrm{~h}$. The results are given in Fig. 4.

\section{Effects of $[\mathrm{NaOH}]$ on silica dissolution}

$\mathrm{SiO}_{2}(1.8 \mathrm{~g}, 30.0 \mathrm{mmol})$ and $25-57.1 \mathrm{~mol} \% \mathrm{NaOH}(0.4-1.6 \mathrm{~g}$, $10-40 \mathrm{mmol}$ ) were added to $50 \mathrm{ml} \mathrm{EGH}$ and standard reaction conditions were applied. The reaction time was set to $1 \mathrm{~h}$. The results are shown in Fig. 5.

\section{Effects of $[\mathrm{NaOH}]$ and $\left[\mathrm{Me}_{4} \mathrm{NCl}\right]$ on silica dissolution} Silica $(1.8 \mathrm{~g}, 30 \mathrm{mmol})$ was mixed with $0-33.3 \mathrm{~mol} \% \mathrm{Me}_{4} \mathrm{NCl}$ $(0-3.3 \mathrm{~g}, 0-30 \mathrm{mmol})$ in $50 \mathrm{ml}$ ethylene glycol and $1.2 \mathrm{~g} \mathrm{NaOH}$ $(0.03 \mathrm{~mol})$ and reacted under standard conditions. The results are shown in Fig. 6.

\section{Combined effects of [NaOH], [Me $\left.{ }_{4} \mathrm{NOH} \cdot 5 \mathrm{H}_{2} \mathrm{O}\right]$ and $\left[\mathrm{Me}{ }_{4} \mathrm{NCl}\right]$ on silica dissolution}

Silica $(1.8 \mathrm{~g}, 30 \mathrm{mmol})$ was mixed with various amounts of $\mathrm{Me}_{4} \mathrm{NOH} 5 \mathrm{H}_{2} \mathrm{O}, \mathrm{Me}_{4} \mathrm{NCl}$ and $\mathrm{NaOH}$ in $50.0 \mathrm{ml}$ ethylene glycol and reacted under standard conditions at $1 \mathrm{~h}$. The results are shown in Fig. 7.

\section{RESULTS AND DISCUSSION}

We have previously shown that alkali and alkaline metal hydroxides or oxides and simple basic amine compounds can dissolve silica at $200^{\circ} \mathrm{C}$ in $\mathrm{EGH}_{2}$ to form both stoichiometric products and polyglycolate complexes per reactions (1)-(3) as shown below. ${ }^{18-20}$ The rates of reaction for the amines studies relate directly to their $\mathrm{p} K_{\mathrm{b}} \mathrm{s}$ (Scheme 1 ) and their ability to chelate silicon. ${ }^{19}$

In these amine promoted reactions, the rates of dissolution at $200^{\circ} \mathrm{C}$ are those shown in Fig. 1 . The amine dissolution rates are much smaller than those found for catalytic amounts of alkali hydroxides, which are up to 10 times faster under the same conditions. ${ }^{19}$ However, the activation energies for dissolution for all the reactions studied ${ }^{18-20}$ are much the same at $\sim 59 \pm 8 \mathrm{~kJ} / \mathrm{mol}$, suggesting a common dissolution mechanism.

The search for ways to improve reactions rates and reduce temperature led to $\mathrm{Me}_{4} \mathrm{NOH}$, used extensively as a very strong base, especially in alcoholic environments. ${ }^{12-14,21}$ In such environments, its $\mathrm{p} K_{\mathrm{b}}$ is not known but is probably of the order of $\mathrm{MeO}^{-}$in methanol based on the work of Cluett among others. ${ }^{14}$ Note that the acidities and basicities of various organic species in nonaqueous solvents have been the subject of much study over long periods of time; however, the estimations of $\mathrm{p} K_{\mathrm{a}}$ and $\mathrm{p} K_{\mathrm{b}}$ and the corresponding solution $\mathrm{pH}$ values, especially for the systems studied here, remains quite difficult, especially where some water is present. $^{21,22}$

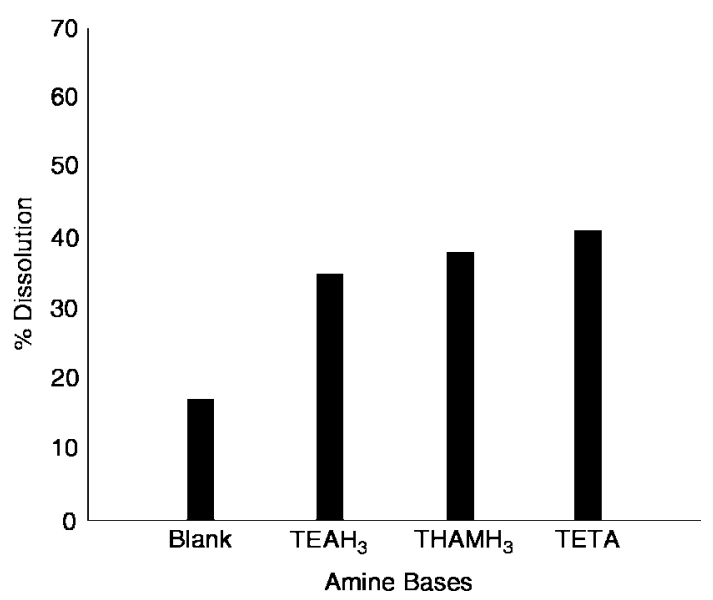

Figure 1. Dissolution of silica at $200^{\circ} \mathrm{C}$ in $\mathrm{EGH}_{2}$ promoted by amine bases from Reference 19.

Appl. Organometal. Chem. 2006; 20: 393-398 


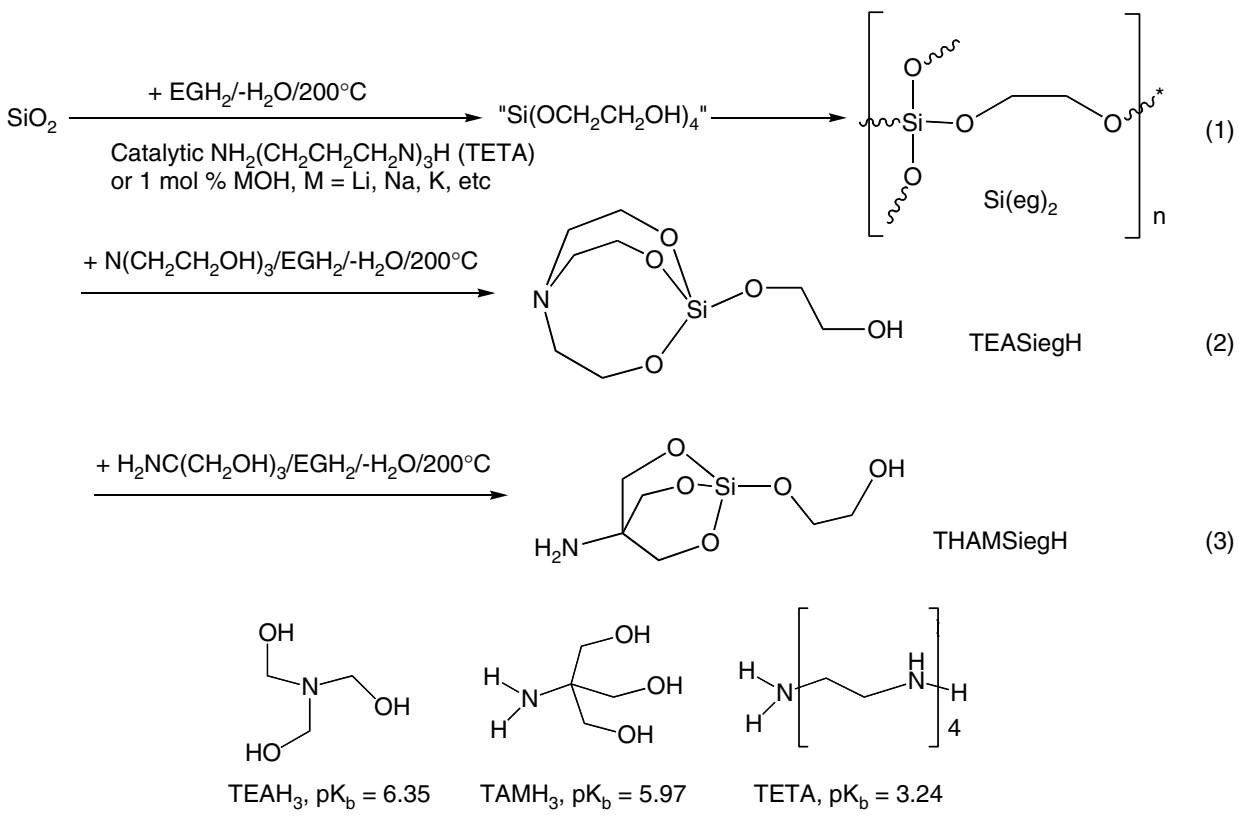

Scheme 1. $\mathrm{p} K_{\mathrm{b}} \mathrm{s}$ of amines in reactions (1)-(3). ${ }^{19}$

As recently noted in our review on the subject, ${ }^{2}$ tetraalkylammonium hydroxides to generate ammonium silicates have been studied extensively. Indeed, in preparing this paper, we discovered that the formation of ammonium polysilicates by reaction of silica with alkylammonium hydroxides was first described in 1951 by Merrill and Spencer, ${ }^{23}$ some 20 years earlier than reported in our review. $^{2}$

The goal of the work described below was to develop an understanding of the reaction of $\mathrm{Me}_{4} \mathrm{NOH}$ with silica for the reasons discussed in the introduction. For example, we hoped to generate $\mathrm{Me}_{4} \mathrm{NOH}$ in situ by mixing $\mathrm{NaOH}$ with $\mathrm{Me}_{4} \mathrm{NCl}$ to form $\mathrm{NaCl}$ using the well-known 'hydroxide synthesis' ${ }^{14-16}$ This approach was predicated on the fact that $\mathrm{NaCl}$ is only modestly soluble in alcohols $(1.4 \mathrm{~g} / 100 \mathrm{ml} \mathrm{MeOH}, 7 \mathrm{~g} / 100 \mathrm{ml}$ $\mathrm{EGH}_{2}$ at $\left.25^{\circ} \mathrm{C}\right)^{24}$ thus creating the possibility of forming it in situ with the idea of using this approach to recycle $\mathrm{Me}_{4} \mathrm{NCl}$ or its choline equivalent. A further goal was to compare silica dissolution with $\mathrm{Me}_{4} \mathrm{NOH}$ with $\mathrm{NaOH}$ promoted dissolution in ethylene glycol $\left(\mathrm{EGH}_{2}\right)$ based on our previous work on this system. ${ }^{18-20}$ These goals provide the basis for the following sets of kinetic studies.

\section{Standard conditions for kinetic studies}

The first step was to establish standard conditions. Thus, all reactions were carried out as follows. A flask containing a mixture of $30 \mathrm{mmol}$ silica and $50 \mathrm{ml} \mathrm{EGH}_{2}$ with various amounts of $\mathrm{NaOH}, \mathrm{Me}_{4} \mathrm{NOH} 5 \mathrm{H}_{2} \mathrm{O}$ or $\mathrm{Me}_{4} \mathrm{NCl}$ was attached to a distillation apparatus above an oil bath pre-heated to $125 \pm 2{ }^{\circ} \mathrm{C}$. The bath was raised to immerse the flask and the reaction was run for a pre-set time. The flask was then cooled quickly in ice water. The undissolved silica yields were then determined as described in the Experimental section and dissolution rates were then calculated. For silica dissolution to proceed, the reaction must be run under conditions where byproduct water is removed continuously. Before our studies began, it was necessary to confirm of the effect of $\mathrm{H}_{2} \mathrm{O}$ contained in commercial $\mathrm{Me}_{4} \mathrm{NOH} 5 \mathrm{H}_{2} \mathrm{O}$.

Commercially available anhydrous $\mathrm{Me}_{4} \mathrm{NOH}$ dissolved in $\mathrm{MeOH}$ was distilled to remove methanol to produce solid $\left(\mathrm{CH}_{3}\right)_{4} \mathrm{NOH}$, presumably without waters of hydration. Thereafter, $30 \mathrm{mmol}$ of this solid $\left(\mathrm{CH}_{3}\right)_{4} \mathrm{NOH}$ and $30 \mathrm{~mm} \mathrm{~mol}$ silica were added to $50 \mathrm{mml}$ of $\mathrm{EGH}_{2}$ and then the standard experimental procedure was run. These reactions were run several times and an average yield of $26.5 \mathrm{~mol} \%$ for silica dissolution was obtained compared with a $27.4 \mathrm{~mol} \%$ yield in case of the pentahydrate. This is within the error limits of our procedure. Thus, the pentahydrate has no apparent effect on silica dissolution. However, one must recall that fumed silica has significant amounts of $\mathrm{Si}-\mathrm{OH}$ species on its surface and this likely serves as an additional source of water during the dissolution process. Because $\mathrm{Me}_{4} \mathrm{NOH}$ is easily degraded to methanol and amine at temperature higher than $130^{\circ} \mathrm{C}$, the reaction temperature was restricted to $125^{\circ} \mathrm{C} \cdot{ }^{22}$

\section{Effects of [ $\left[\mathrm{Me}_{4} \mathrm{NOH}^{\cdot} 5 \mathrm{H}_{2} \mathrm{O}\right]$ on silica dissolution} The first set of kinetic studies established the effects of changes in $\mathrm{Me}_{4} \mathrm{NOH} 5 \mathrm{H}_{2} \mathrm{O}$ concentration on dissolution rates. Using the standard experimental procedure, 33-100 $\mathrm{mol} \%$ $\mathrm{Me}_{4} \mathrm{NOH} 5 \mathrm{H}_{2} \mathrm{O}$ (vs $\mathrm{SiO}_{2}$ added) was reacted with a known amount of silica with a reaction time of $1 \mathrm{~h}$. The dissolution yields are plotted in Fig. 2 and indicate that there is a linear dependence on silica dissolution. As noted in our 


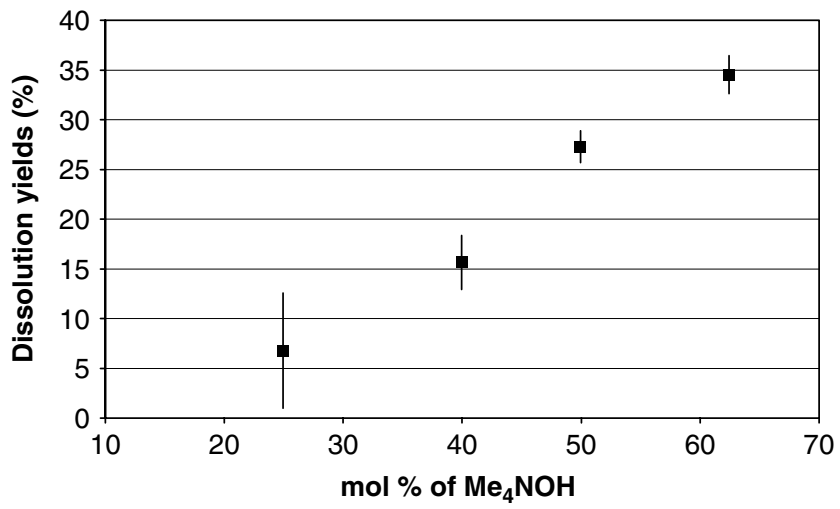

Figure 2. Dissolution of silica (mol\%) as a function of $\mathrm{Me}_{4} \mathrm{NOH}^{5} 5 \mathrm{H}_{2} \mathrm{O}$ concentration. The plot is of mol\% $\mathrm{Me}_{4} \mathrm{NOH} \cdot 5 \mathrm{H}_{2} \mathrm{O}$ vs mol\% $\mathrm{SiO}_{2}$ used.

previous work, ${ }^{19}$ and in contrast to the $\mathrm{NaOH}$ studies, $\mathrm{Me}_{4} \mathrm{NOH} 5 \mathrm{H}_{2} \mathrm{O}$ does not promote the catalytic dissolution of silica. Consequently the mechanism of dissolution must change, as discussed in our RHA dissolution paper. ${ }^{1}$

\section{Effects of reaction time on dissolution rates}

In order to observe the effect of reaction time on silica dissolution, $\mathrm{SiO}_{2}(1.8 \mathrm{~g}, 30.0 \mathrm{mmol})$ and $\mathrm{Me}_{4} \mathrm{NOH} 5 \mathrm{H}_{2} \mathrm{O}$ $(5.5 \mathrm{~g}, 30 \mathrm{mmol})$ were added to $50 \mathrm{ml} \mathrm{EGH}_{2}$ and reacted under standard conditions for periods of 1-4h. As shown in Fig. 3, silica dissolution is linearly dependent with time. The intercept dissolution is about $15 \mathrm{~mol} \%$ silica, as expected. This is identical within error limits to the blank studies done when $\mathrm{N}_{\mathrm{a}} \mathrm{OH}$ was used to promote dissolution. ${ }^{19}$ These results confirm the fact that dissolution is a stoichiometric reaction, and also suggest that there is no degradation of $\mathrm{Me}_{4} \mathrm{NOH} \cdot 5 \mathrm{H}_{2} \mathrm{O}$ with time.

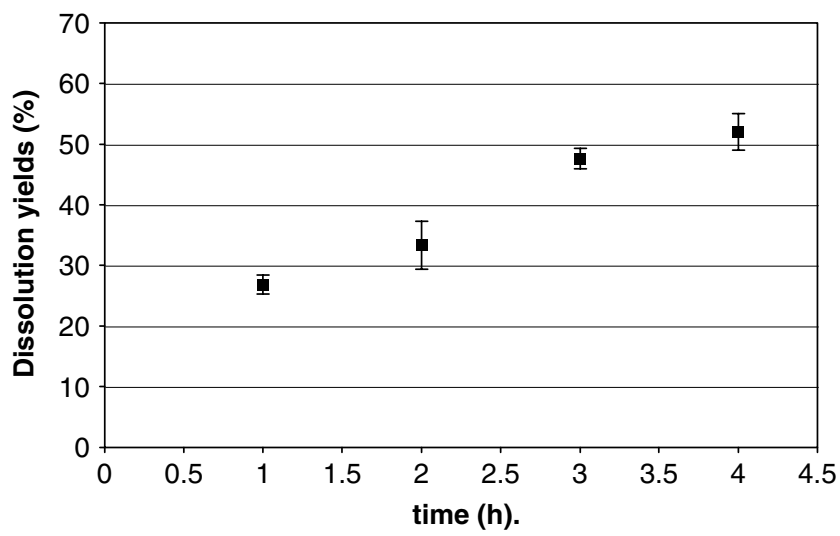

Figure 3. Dissolution of silica (mol\%) as a function of time under standard conditions.

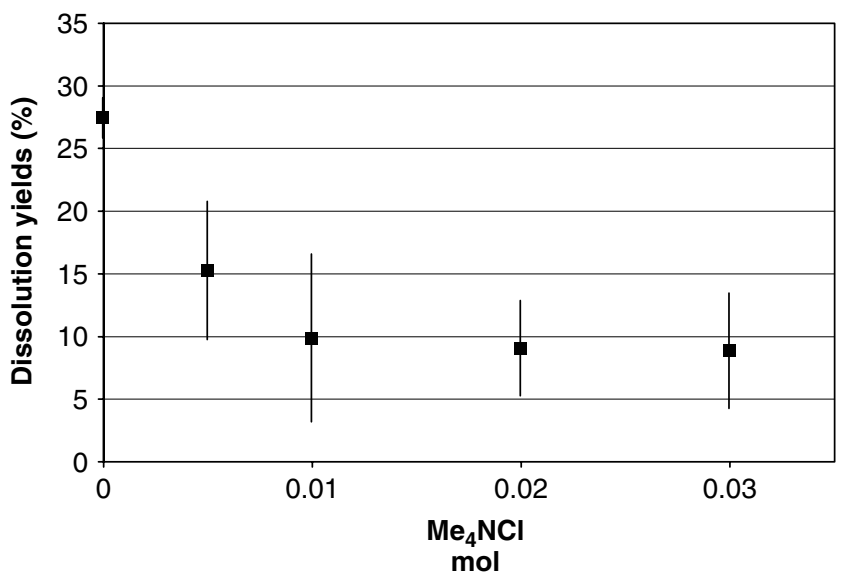

Figure 4. Dissolution of silica (mol\%) vs added $\mathrm{Me}_{4} \mathrm{NCl}$ under standard conditions.

\section{Effects of added $\mathrm{Me}_{4} \mathrm{NCl}$ on dissolution rates}

A third set of kinetic studies was carried out to examine the combined effects of $\mathrm{Me}_{4} \mathrm{NCl}$ and $\mathrm{Me}_{4} \mathrm{NOH}_{5} 5 \mathrm{H}_{2} \mathrm{O}$ on silica dissolution. In this set $5.5 \mathrm{~g} \mathrm{Me}_{4} \mathrm{NOH} 5 \mathrm{H}_{2} \mathrm{O}(30 \mathrm{mmol})$ was used with incremental amounts of $\mathrm{Me}_{4} \mathrm{NCl}$ added as shown in Fig. 4. Surprisingly $\mathrm{Me}_{4} \mathrm{NCl}$ strongly inhibits silica dissolution as shown clearly.

We offer the following explanations but must emphasize that these are quite speculative. First, it is likely that $\mathrm{Me}_{4} \mathrm{NCl}$ dissolves in relatively polar $\mathrm{EGH}_{2}$ to form individual ions. Given that $\mathrm{Me}_{4} \mathrm{~N}^{+}$is unlikely to form strong associations with any anion (including $\mathrm{Cl}^{-}$), this may leave the chloride free to act as a nucleophile with $\mathrm{Si}(\mathrm{O})_{x}$ surface species to preferentially form pentacoordinated $\left[\mathrm{Si}(\mathrm{O})_{x} \mathrm{Cl}\right]^{-}$ rather than $\left[\mathrm{Si}(\mathrm{O})_{x} \mathrm{OH}\right]^{-}$species. $\left[\mathrm{Si}(\mathrm{O})_{x} \mathrm{OH}\right]^{-}$may be the first intermediate formed during $\mathrm{Me}_{4} \mathrm{NOH}$ promoted silica dissolution in analogy to the pentacoordinated glycolato-silicate species we proposed for alkali glycolate promoted dissolution of silica. ${ }^{19}$ Such a species would then coat the surface limiting access of $\mathrm{Me}_{4} \mathrm{NOH}$ to the silica surface thereby inhibiting extraction of silicon species.

Alternately, a cluster complex may form between the $\mathrm{Me}_{4} \mathrm{NCl} / \mathrm{Me}_{4} \mathrm{NOH}$ species, perhaps like a micelle, trapping all the ionic species in a 'hydrophobic' cage. Such behavior with alkyl ammonium species is known. ${ }^{2}$

A third explanation offered by one of the referees is that the $\mathrm{TMACl}$ may inhibit formation of silica intermediate species that form in solution and thereafter condense to OA by greatly reducing the solubility of these intermediates in solution. This may be equivalent to above suggestion about formation of $\left[\mathrm{Si}(\mathrm{O})_{x} \mathrm{Cl}\right]^{-}$species.

\section{Effects of $[\mathrm{NaOH}]$ on silica dissolution}

Because we were interested in generating $\mathrm{Me}_{4} \mathrm{NOH}$ from $\mathrm{NaOH}$ and $\mathrm{Me}_{4} \mathrm{NCl}$, the effect of chloride seems problematic; 
nonetheless we attempted to add $\mathrm{NaOH}$ to the system to see if we could promote formation of $\mathrm{Me}_{4} \mathrm{NOH}$ directly.

$\mathrm{SiO}_{2}(1.8 \mathrm{~g}, 30.0 \mathrm{mmol})$ and $25-60 \mathrm{~mol} \% \mathrm{NaOH}(0.4-1.6 \mathrm{~g}$, $10-40 \mathrm{mmol}$ ) were added to $50 \mathrm{ml} \mathrm{EGH}_{2}$ and reacted under standard conditions. The reaction time was set to $1 \mathrm{~h}$. The results are shown in Fig. 5 and are identical to our previous studies showing the same blank intercept and catalytic dissolution, something not possible with $\mathrm{Me}_{4} \mathrm{NOH} 5 \mathrm{H}_{2} \mathrm{O} .{ }^{19}$

Another set of kinetic studies was carried out to examine the combined effects of $\mathrm{Me}_{4} \mathrm{NCl}$ and $\mathrm{NaOH}$ on silica dissolution. Thus, $1.2 \mathrm{~g} \mathrm{NaOH}$ (30 mmol) was used for this set of studies with incremental amounts of $\mathrm{Me}_{4} \mathrm{NCl}$. In this instance, the effect of $\mathrm{Me}_{4} \mathrm{NCl}$ on silica dissolution is mixed per Fig. 6. For example, reacting $30 \mathrm{mmol}$ of $\mathrm{NaOH}$ with $10 \mathrm{mmol}$ of $\mathrm{Me}_{4} \mathrm{NCl}$ leaves $20 \mathrm{mmol}$ of unreacted $\mathrm{NaOH}$ which can

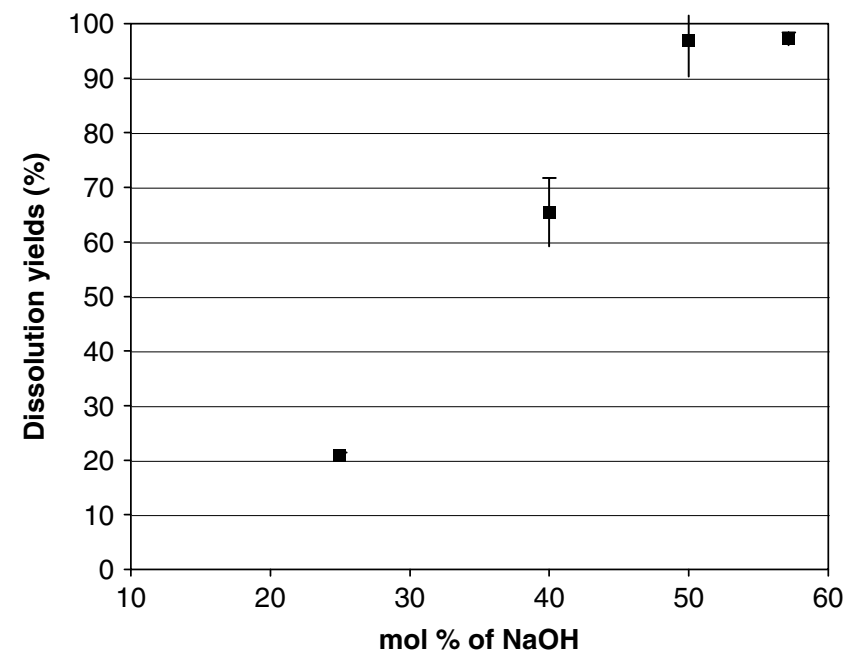

Figure 5. Dissolution of silica (mol\%) as a function of added $\mathrm{NaOH}(\mathrm{mol} \%)$ under standard conditions. Data points with no visible error bars were reproduced within the data point size. dissolve silica. In this case, the silica dissolution yield is $\sim 30 \%$. In contrast, in Fig. 5, the use of $20 \mathrm{mmol}(20 \mathrm{~mol} \%$ ) $\mathrm{NaOH}$ gave $21 \%$ dissolution under standard conditions, about equivalent to a blank reaction. This suggests that the surface acidity of the silica itself may neutralize some of the base. Also, the improved yields with $\mathrm{Me}_{4} \mathrm{NCl}$, may again suggest that some form of complex with groups at the surface occurs. However, this is only speculative and requires further substantiation.

\section{Combined effect of $\mathrm{Me}_{4} \mathrm{NOH}$ and $\mathrm{NaOH}$ for silica dissolution}

One final set of studies was run with a mixture to see if it was possible to observe silica dissolution from a combined system at various ratios. This has practical implications for using these materials for large scale synthesis of the octaanion and nanocomposite precursors thereafter as discussed above.

A set of kinetic studies was carried out using the compositions in Table 1, to examine the combined effect of $\mathrm{Me}_{4} \mathrm{NOH} 5 \mathrm{H}_{2} \mathrm{O}$, and $\mathrm{NaOH}$ on silica dissolution at constant $\left[\mathrm{Me}_{4} \mathrm{NCl}\right]$. The resulting data are plotted in Fig. 7.

The efficiency of equimolar concentrations of $\mathrm{NaOH}$ and $\mathrm{Me}_{4} \mathrm{NOH} 5 \mathrm{H}_{2} \mathrm{O}$ is higher than two equivalents of $\mathrm{Me}_{4} \mathrm{NOH}$ and lower than two equivalents of $\mathrm{NaOH}$. However, Hasegawa has already pointed out that the presence of $\mathrm{Na}^{+}$ ions controls the equilibrium between formation of octaanion

Table 1. Effects of $\mathrm{NaOH}$ and $\mathrm{Me}_{4} \mathrm{NOH} 5 \mathrm{H}_{2} \mathrm{O}$ on silica dissolution

\begin{tabular}{lrrr}
\hline Experiment number & 1 & 2 & 3 \\
\hline $\mathrm{NaOH}(\mathrm{mol} \%)$ & 40 & 20 & 0 \\
$\mathrm{Me}_{4} \mathrm{NOH}(\mathrm{mol} \%)$ & 0 & 20 & 40 \\
$\mathrm{Me}_{4} \mathrm{NCl}(\mathrm{mol} \%)$ & 3 & 3 & 3 \\
\hline
\end{tabular}

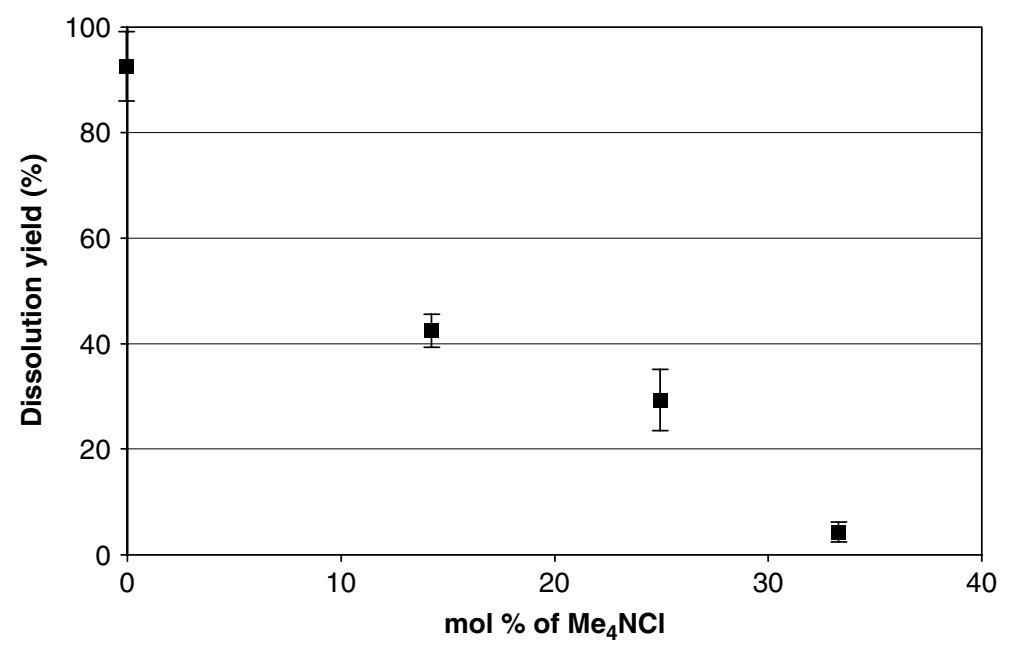

Figure 6. Silica dissolution vs added $\mathrm{Me}_{4} \mathrm{NCl}$ with $0.03 \mathrm{~mol} \mathrm{NaOH}$ under standard conditions. 


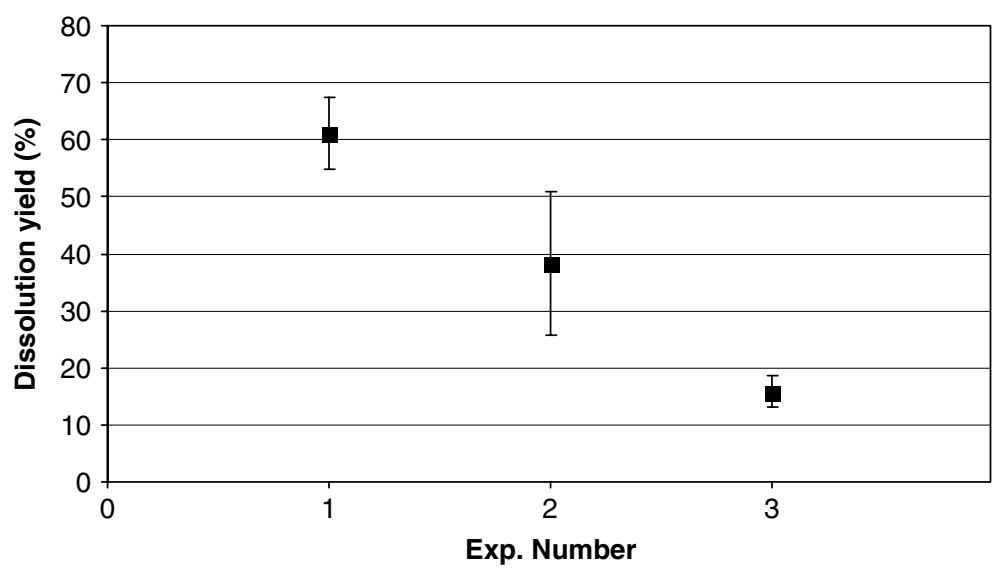

Figure 7. The effects of $\mathrm{NaOH}$ and $\mathrm{Me}_{4} \mathrm{NOH}^{5} 5 \mathrm{H}_{2} \mathrm{O}$ on silica dissolution.

and simple sodium silicates, suggesting that this approach while effective vis a vis silica dissolution will not offer improved yields of octaanion.

\section{CONCLUSIONS}

During studies designed to explore the in situ generation of $\mathrm{Me}_{4} \mathrm{NOH}$ from $\mathrm{NaOH}$ and $\mathrm{Me}_{4} \mathrm{NCl}$, to promote silica dissolution with subsequent formation of the $\left[{ }^{-} \mathrm{OSiO}_{1.5}\right]_{8}{ }^{8-}$ nanobuilding block, we find that $\mathrm{Me}_{4} \mathrm{NCl}$ strongly inhibits silica dissolution. These results are quite surprising and although no immediate rationale for this behavior can be offered, we suggest that the formation of some form of surface species prevents reaction of $\mathrm{OH}^{-}$with the silica surface. It may be that $\mathrm{Cl}^{-}$forms a pentacoordinate surface species in preference to a pentacoordinate hydroxide. This will require additional research to prove.

\section{Acknowledgments}

K.H.K. wishes to thank Korean Chemical Company for a generous leave of absence. R.M. Laine would like to thank the USDA through SBIR Contract 2005-00442 to Mayaterials Inc. for partial support of this work. We would also like to thank the referees for critical comments that made this a much better paper.

\section{REFERENCES}

1. Asuncion MZ, Hasegawa I, Kampf J, Laine RM. J. Mater. Chem. 2005; 15: 2114.
2. Laine RM. J. Mater. Chem. 2005; 15: 3725.

3. Zhang C, Laine RM. J. Am. Chem. Soc. 2000; 122: 6979.

4. Laine RM, Choi J, Lee I. Adv. Mater. 2001; 13: 800.

5. Costa ROR, Vasconcelos WL, Tamaki R, Laine RM. Macromolecules 2001; 34: 5398.

6. Neumann D, Fisher M, Tran L, Matisons JG. J. Am. Chem. Soc. 2002; 124: 13998.

7. Moran M, Casado CM, Cuadrado I, Losada J. Organometals 1993; 12: 4327.

8. Jutzi P, Batz C, Mutluay A. Eightfold Functionalization of the Octasilsesquioxane Core. Verlag der Zietschrift für Naturforschung: $1994 ; 1689$.

9. Mehl GH, Goodby JW. Angew. Chem. 1996; 35: 2641.

10. Sellinger A, Laine RM. Macromolecules 1996; 29: 2327.

11. Choi J, Harcup J, Yee AF, Zhu Q, Laine RM. J. Am. Chem. Soc. 2001; 123: 11420.

12. Harlow GA, Wyld GEA. Anal. Chem. 1962; 34: 172.

13. Harlow GA. Anal. Chem. 1962; 34: 1487.

14. Cluett ML. Anal. Chem. 1959; 31: 610.

15. Harris RK, Knight CTG, Hull WE. J. Am. Chem. Soc. 1981; 103 1577.

16. Hasegawa I, Sakka S, Kuroda K, Kato C. Bull. Inst. Chem. Res. Kyoto Univ. 1987; 65: 5.

17. Lentz CW. Inorg. Chem. 1964; 3: 574.

18. Laine RM, Blohowiak KY, Robinson TR, Hoppe ML, Nardi P, Kampf J, Uhm J. Nature 1991; 353: 642.

19. Cheng H, Tamaki R, Laine RM, Babonneau F, Chujo Y, Treadwell DR. J. Am. Chem. Soc. 2000; 122: 10063.

20. Hoppe ML, Laine RM, Kampf J, Gordon MS, Burggraf LW. Angew. Chem. Int. 1993; 32: 287.

21. Bowden K, Buckley A, Steward R. J. Am. Chem. Soc. 1996; 88: 947.

22. Stewart TD, Aston JG. J. Am. Chem. Soc. 1926; 49: 1718.

23. Merrill RC, Spencer RW. J. Phys. Coll. Chem. 1951; 55: 187.

24. Kraus KA, Raridon RJ, Baldwin WH. J. Am. Chem. Soc. 1964; 86: 2571. 